\title{
Optimization of Pickling Solution for Improving the Phosphatability of Advanced High-Strength Steels
}

\author{
Sangwon Cho ${ }^{1}$, Sang-Jin Ko ${ }^{1}$, Jin-Seok Yoo ${ }^{1}$, Joong-Chul Park ${ }^{2}$, Yun-Ha Yoo ${ }^{2}$ and Jung-Gu Kim ${ }^{1, *}$ \\ 1 Department of Materials Science and Engineering, Sungkyunkwan University, Suwon-Si 16419, Korea; \\ ppkh@skku.edu (S.C.); tkdwls121@skku.edu (S.-J.K.); wlstjr5619@skku.edu (J.-S.Y.) \\ 2 Steel Solution Marketing Dept., POSCO Global R\&D Center, Incheon 21985, Korea; \\ heavymetal@posco.com (J.-C.P.); yunha778@posco.com (Y.-H.Y.) \\ * Correspondence: kimjg@skku.edu; Tel.: +82-31-290-7360
}

Citation: Cho, S.; Ko, S.-J.; Yoo, J.-S.; Park, J.-C.; Yoo, Y.-H.; Kim, J.-G. Optimization of Pickling Solution for Improving the Phosphatability of Advanced High-Strength Steels. Materials 2021, 14, 233. https:// doi.org/10.3390/ma14010233

Received: 2 December 2020 Accepted: 30 December 2020 Published: 5 January 2021

Publisher's Note: MDPI stays neutral with regard to jurisdictional clai$\mathrm{ms}$ in published maps and institutional affiliations.

Copyright: $\odot 2021$ by the authors. Licensee MDPI, Basel, Switzerland. This article is an open access article distributed under the terms and conditions of the Creative Commons Attribution (CC BY) license (https:// creativecommons.org/licenses/by/ $4.0 /)$.

\begin{abstract}
This study investigated the optimum pickling conditions for improving the phosphatability of advanced high-strength steel (AHSS) using surface analysis and electrochemical measurements. To remove the $\mathrm{SiO}_{2}$ that forms on the surface of AHSS, $30 \mathrm{wt} \% \mathrm{NH}_{4} \mathrm{HF}_{2}$ was added to the pickling solution, resulting in a significant reduction in the amount of $\mathrm{SiO}_{2}$ remaining on the surface of the AHSS. The phosphatability was improved remarkably using $\mathrm{HNO}_{3}$ concentrations higher than $13 \%$ in the pickling solution. Furthermore, phosphate crystals became finer after pickling with a $\mathrm{HNO}_{3}$ based solution rather than a HCl-based solution. Electrochemical impedance spectroscopy (EIS) data indicated that the corrosion resistance of AHSS subjected to $\mathrm{HNO}_{3}$-based pickling was higher than that of AHSS subjected to HCl-based pickling. Fluorine compounds, which were involved in the phosphate treatment process, were only formed on the surface of steel in $\mathrm{HNO}_{3}$-based solutions. The $\mathrm{F}$ compounds reacted with the phosphate solution to increase the $\mathrm{pH}$ of the bulk solution, which greatly improved the phosphatability. The phosphatability was better under $\mathrm{HNO}_{3}$-based conditions than a HCl-based condition due to the fineness of the phosphate structure and the increased surface roughness.
\end{abstract}

Keywords: advanced high-strength steel; phosphate coating; acid cleaning; electrochemical impedance spectroscopy

\section{Introduction}

Consumer demand for automobiles has been increasing over the last decade, with particular regard for features such as appearance, driving performance, comfort, safety, fuel efficiency, and environmental friendliness. In response, the automotive industry has spurred the development of new and advanced technologies to improve safety while reducing vehicle weight. However, the technology used to manufacture lightweight automobiles is associated with environmental problems [1]. Research into automotive weight reduction can be divided into the fields of lightweight materials and high-strength steel sheets [2]. Studies on the use of lightweight materials for automobiles have mainly focused on aluminum and fiber-reinforced plastics [3-5], but the practical use of these materials is difficult due to product design limitations and manufacturing problems. However, high-strength materials can be used without making significant changes to conventional manufacturing methods, so they have the advantage of minimal additional investment costs. In addition, multi-material applications can be used with high-strength materials, depending on the function of the component; thus, a variety of designs are possible. Another advantage of using high-strength materials is that reductions in the thickness and weight of the material are obtained at the same time. Therefore, various grades of steel, from mild steel to advanced high-strength steel (AHSS), have been used in recent automotive bodies. In addition, steel manufacturers are actively researching applications for more advanced steel sheets to further reduce the weight. 
Generally, a steel sheet for automobiles is subjected to a phosphate treatment to improve corrosion resistance and ensure coating film adhesion before painting [6,7]. Phosphate crystals form on the steel sheet surface from the phosphate treatment, which greatly enhances the adhesion of electro-painting [7]. The size of the phosphate crystals and coating weight are very important factors: relatively small crystals result in the formation of denser phosphate crystals, resulting in better adhesion to the coating.

During phosphate treatment, an acidic zinc phosphate solution reacts with the surface of the metal and consumes hydrogen ions in the solution. This reaction increases the $\mathrm{pH}$ near the metal surface. Then, the phosphate solution is saturated with zinc phosphate. As a result of the increase in $\mathrm{pH}$, the formation of phosphate crystals is promoted. Therefore, phosphatability can be improved by an accelerator that increases the rate of hydrogen ion consumption on the metal surface [8].

Alloy elements such as $\mathrm{Si}$ and $\mathrm{Mn}$ are indispensable elements for obtaining high strength and high ductility. Therefore, AHSS has a higher content of these alloying elements compared to general steels. However, during steel manufacturing and use, $\mathrm{Si}$ and $\mathrm{Mn}$ oxides are easily formed on the steel surface. When these composite oxides densely form on the surface of a steel sheet, they have a significant effect on the phosphate treatment. In particular, a Si oxide film that forms on the AHSS surface acts as a barrier to phosphating, thereby decreasing the phosphatability [9]. Therefore, to improve the phosphatability of AHSSs that contain a large amount of $\mathrm{Si}$, the formation of these oxides on the surface of the steel must be suppressed.

Currently, two main methods are used to remove the Si oxide that forms on the surface of AHSS. The first method uses a high-temperature, high-concentration inorganic acid (e.g., hydrochloric acid, sulfuric acid, nitric acid, or formic acid) solution, which removes the Si oxide by dissolving the base metal under the Si oxide [10]. In this method, if the concentration of the inorganic acid is low, the Si oxide on the surface is not removed; conversely, if the concentration is too high, over-etching occurs and the material cannot be used in automotive manufacturing. Therefore, it is important to appropriately control the concentration of the inorganic acid.

The second method utilizes hydrofluoric acid (HF) in a pickling solution to remove the Si oxide, using the following reaction:

$$
\mathrm{SiO}_{2}+4 \mathrm{HF} \rightarrow \mathrm{SiF}_{4}+2 \mathrm{H}_{2} \mathrm{O}
$$

This method does not use HF alone; rather, HF is mixed with an inorganic acid to activate its reaction [11]. However, because HF is very dangerous, it is challenging to use it in a pickling solution. To react with silicate, which is a basic form of Si oxide, $\mathrm{F}^{-}$is required. Therefore, many researchers have attempted to replace HF with ammonium fluoride $\left(\mathrm{NH}_{4} \mathrm{~F}\right)$ and ammonium hydrogen fluoride $\left(\mathrm{NH}_{4} \mathrm{HF}_{2}\right)$ as a new source of $\mathrm{F}^{-}$because they are eco-friendly and less hazardous than $\mathrm{HF} . \mathrm{NH}_{4} \mathrm{~F}$ and $\mathrm{NH}_{4} \mathrm{HF}_{2}$ have been used in a mixture with an inorganic acid solution; the etching rate can be adjusted by controlling the type and concentration of the inorganic acid [12]. Because $\mathrm{NH}_{4} \mathrm{HF}_{2}$ has more $\mathrm{F}$ than $\mathrm{NH}_{4} \mathrm{~F}$, its etching efficiency is better and its cost is lower; thus, it is suitable as a HF substitute.

Although many studies on the phosphatability of AHSS have been carried out, some problems still exist, such as a decrease in phosphatability due to Si oxides. The phosphatability of AHSS under the conventional pickling conditions used in industry are not optimal; as shown in Figure 1, the coating coverage and the coating weight are insufficient. Therefore, in this study, we investigated the optimum pickling conditions to improve the phosphatability of AHSS while minimizing environmental hazard. 


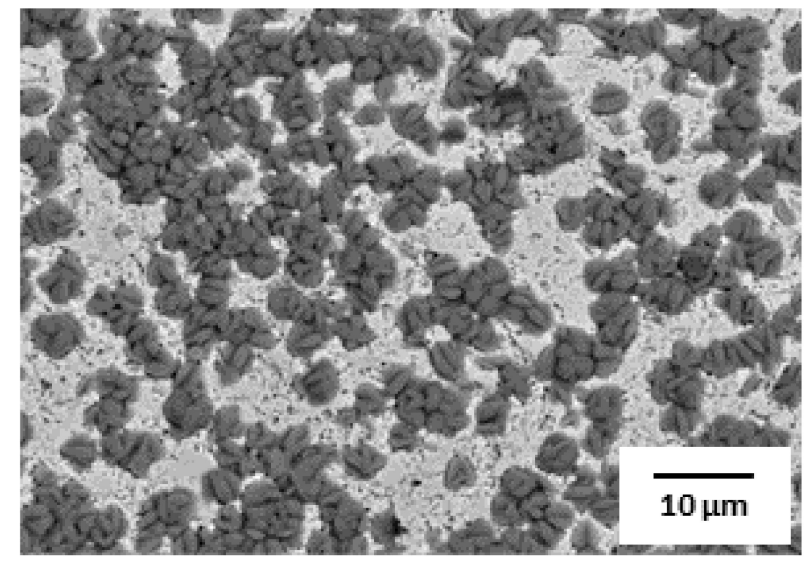

Figure 1. Surface SEM image of advanced high-strength steel (AHSS) after phosphate treatment under the conventional pickling condition.

\section{Materials and Methods}

The specimens used in the experiment were AHSSs with Si contents of 0.4 and 1.0, as described in Table 1 . The specimens were dipped in an alkaline solution at $45^{\circ} \mathrm{C}$ for $2 \mathrm{~min}$ for degreasing before testing. The phosphate treatment process was divided into two steps: pickling and phosphating. As listed in Table 2, the pickling solutions used in the experiment were prepared by adding $30 \mathrm{wt} . \% \mathrm{NH}_{4} \mathrm{HF}_{2}$ to $\mathrm{HCl}$ and $\mathrm{HNO}_{3}$ at various concentrations $(5.5,8,10.5,13,15.5$, and $18 \mathrm{wt} . \%)$. Pickling tests were performed at $55^{\circ} \mathrm{C}$ for $7 \mathrm{~s}$. Then, after a degreasing and surface conditioning process, phosphate treatment was performed in a $\mathrm{Zn}$-phosphate solution according to the common automotive process.

Table 1. Chemical compositions of the steels. (Unit: wt.\%).

\begin{tabular}{cccccc}
\hline Grade & C & Mn & Si & P & S \\
\hline 0.4Si steel & 0.17 & 2.8 & 0.25 & 0.02 & 0.005 \\
1.0Si steel & 0.1 & 2.8 & 1.2 & 0.03 & 0.003 \\
\hline
\end{tabular}

Table 2. Pickling conditions for the steels.

\begin{tabular}{cccc}
\hline Parameter & $\begin{array}{c}\text { Conventional } \\
\text { Pickling Condition }\end{array}$ & $\begin{array}{c}\text { HCl-Based } \\
\text { Pickling Condition }\end{array}$ & $\begin{array}{c}\mathrm{HNO}_{3} \text {-Based } \\
\text { Pickling Condition }\end{array}$ \\
\hline $\begin{array}{c}\text { Inorganic acid } \\
\text { Acid concentration } \\
\text { (wt. } \% \text { ) }\end{array}$ & $\mathrm{HCl}$ & $\mathrm{HCl}$ & $\mathrm{HNO}_{3}$ \\
Additives & $5.5,18$ & $5.5,8,10.5,13,15.5,18$ & $5.5,8,10.5,13,15.5,18$ \\
Temperature $\left({ }^{\circ} \mathbf{C}\right)$ & - & $\mathrm{NH}_{4} \mathrm{HF}_{2}(30 \mathrm{wt} \%)$ & $\mathrm{NH}_{4} \mathrm{HF}_{2}(30 \mathrm{wt} . \%)$ \\
Time (s) & 55 & 55 & 55 \\
\hline
\end{tabular}

Phosphatability was evaluated by coating coverage and coating weight. In an image obtained using the back scattered electron (BSE) mode in scanning electron microscopy (SEM; JSM-6700F, JEOL Ltd., Akishima, Japan), a difference in brightness existed between the areas where phosphate crystals were formed and where they did not form. The difference between the light and dark was measured to determine coating coverage using Image J S/W (Laboratory for Optical and Computational Instrumentation, University of Wisconsin). The coating weight was analyzed using energy dispersive $\mathrm{X}$-ray fluorescence (EDXRF; EDX-8000, SHIMADZU, Kyoto, Japan). After calibrating the P signal detected in a standard specimen of known phosphate coating thickness, the coating weight can be calculated by multiplying the measured P signal by density. The oxides that remained on the steel surface after pickling were analyzed using secondary ion mass spectrometry 
(SIMS; TOF-SIMS-5, Ion-ToF company, Munster, Germany), X-ray diffraction (XRD; D/max2500V/PC, Rigaku, Tokyo, Japan), energy dispersive spectroscopy (EDS; JEOL JSM-6700F, JEOL Ltd., Akishima, Japan), and an electron probe micro-analyzer (EPMA; JEOL, JXA8530F, JEOL Ltd., Akishima, Japan).

Electrochemical impedance spectroscopy (EIS; VSP300, Neoscience, Seoul, Korea) tests were performed with an amplitude of $10 \mathrm{mV}$ in the frequency range of $100 \mathrm{kHz}$ to 1 $\mathrm{mHz}$. The electrochemical cell consisted of a three-electrode system. The counter electrode was a graphite rod, and a saturated calomel electrode was used as the reference electrode. The area exposed to the electrolyte was $1 \mathrm{~cm}^{2}$. The test solution was a cyclic corrosion test solution from the Society of Automotive Engineering (SAE solution), and its chemical composition is listed in Table 3. EIS data were fit to the form of a Bode plot, and Bode spectra were fit to equivalent circuit models by using ZSimpWin software (Ver. 3.21).

Table 3. Chemical composition of Society of Automotive Engineering (SAE) solution.

\begin{tabular}{ccccc}
\hline Chemicals & $\mathbf{N a C l}$ & $\mathbf{C a C l}_{\mathbf{2}}$ & $\mathbf{N a H C O}_{3}$ & $\mathbf{( N H}_{\mathbf{4}} \mathbf{2}_{\mathbf{2}} \mathbf{S O}_{4}$ \\
\hline $\begin{array}{c}\text { SAE solution } \\
(\text { wt. } \%)\end{array}$ & 0.05 & 0.1 & 0.075 & 0.35 \\
\hline
\end{tabular}

To analyze the $\mathrm{pH}$ change of the phosphate solution due to the oxides, $1 \mathrm{M}$ of the iron oxides and the F compounds generated during pickling were dissolved in the phosphate solution. The change in $\mathrm{pH}$ was measured using a $\mathrm{pH}$ meter. To analyze the correlation between surface roughness and phosphatability, the surface roughness of the specimen after pickling was measured using an $\alpha$-step (Alpha-Step IQ, KLA-Tencor, Milpitas, CA, USA).

\section{Results and Discussion}

\subsection{Surface Analysis}

Figures 2 and 3 show the amount of $\mathrm{SiO}_{2}$ remaining on the 1.0Si steel surface layer as analyzed by TOF-SIMS and XPS after pickling with various solutions. Figure 2a shows a conventional pickling condition, in which the amount of $\mathrm{SiO}_{2}$ remaining on the surface is larger and the distribution of $\mathrm{SiO}_{2}$ is more uneven than under the other pickling conditions. In Figure 2b,c, however, in the pickling solutions with added $\mathrm{NH}_{4} \mathrm{HF}_{2}$, the $\mathrm{SiO}_{2}$ on the steel surface was noticeably reduced, even though it was not completely removed. Figure 3 shows that the intensity of the $\mathrm{SiO}_{2}$ peak in the pickling solution with added $\mathrm{NH}_{4} \mathrm{HF}_{2}$ was reduced compared with the intensity of the $\mathrm{SiO}_{2}$ peak under conventional pickling conditions. Thus, the amount of $\mathrm{SiO}_{2}$ remaining on the surface was significantly reduced by $\mathrm{NH}_{4} \mathrm{HF}_{2}$-added pickling.
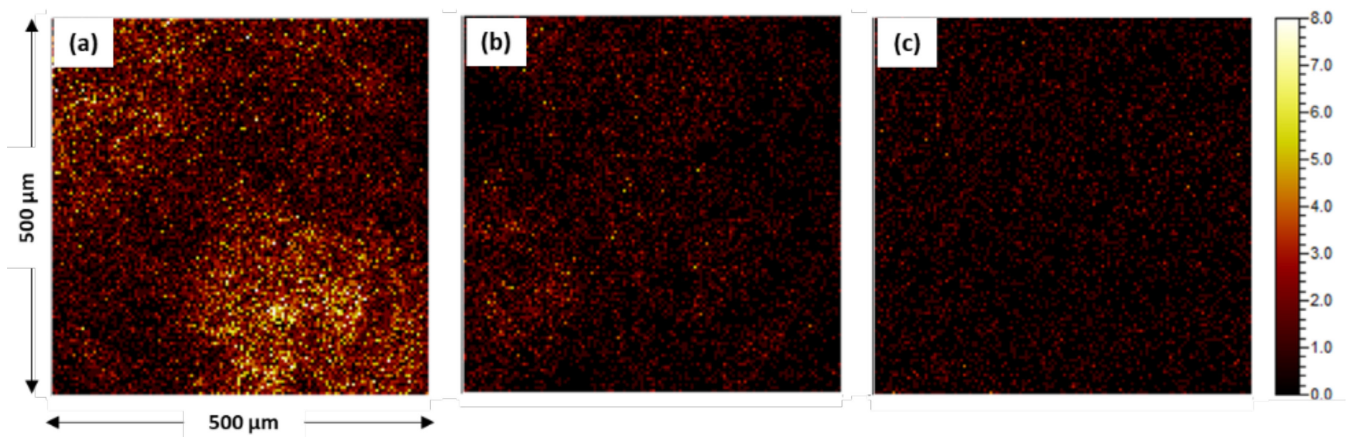

Figure 2. TOF-secondary ion mass spectrometry (SIMS) images of $\mathrm{SiO}_{2}$ remaining on the 1.0Si steel surface after pickling under (a) conventional condition, (b) a $\mathrm{HCl}$-based condition, and (c) a $\mathrm{HNO}_{3}$-based condition. 


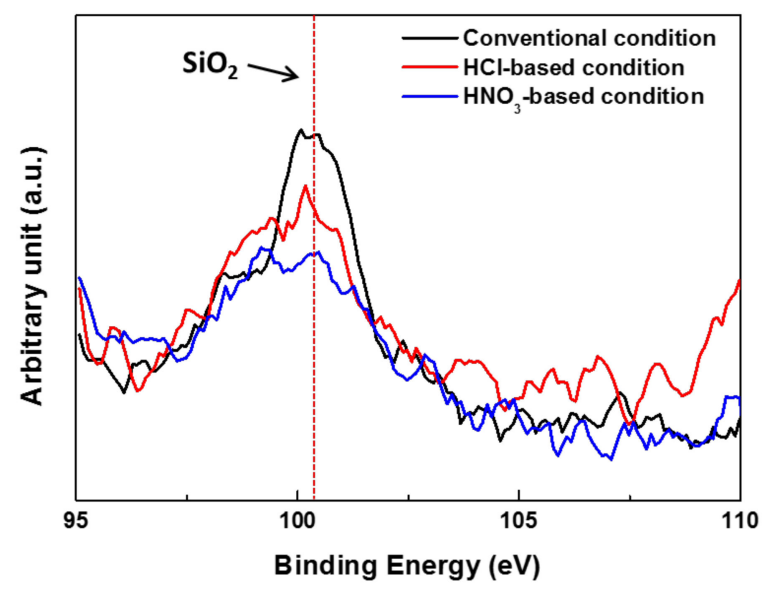

Figure 3. XPS spectra of Si on the 1.0Si steel surface after pickling.

After the pickling of 1.0Si steel under various conditions, the surface was analyzed with optical microscopy $(\mathrm{OM})$, as shown in Figure 4. The surface of the specimen before and after $\mathrm{HCl}$-based pickling was the same; however, after $\mathrm{HNO}_{3}$-based pickling, the surface of the specimen was uniformly covered with a new gray product. Figures $5-7$ and Table 4 reveal the oxides that remained on the surface after pickling, as analyzed by EDS, EPMA, and XRD.
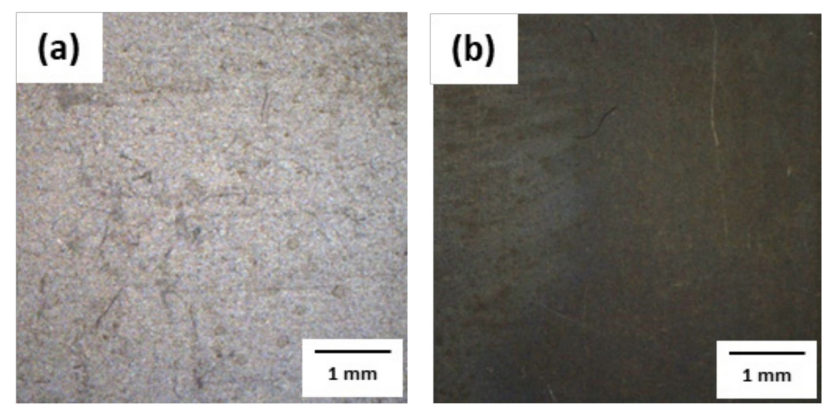

Figure 4. Optical microscopy (OM) images of the 1.0Si steel surface after pickling under (a) a $\mathrm{HCl}$-based condition and (b) a $\mathrm{HNO}_{3}$-based condition.

As shown in Figure 5, the EDS peaks of $\mathrm{O}, \mathrm{Si}, \mathrm{Cr}$, and $\mathrm{Fe}$ can be observed from 1.0Si steel under all pickling conditions, indicating that the remaining oxides on the surface were mainly $\mathrm{Fe}, \mathrm{Cr}$, and $\mathrm{Si}$ oxides. However, the $\mathrm{F}$ peak was observed only under $\mathrm{HNO}_{3}$-based pickling conditions. The results of EPMA analysis (Figure 6) were similar to those of EDS: an $\mathrm{F}$ component was observed throughout the surface only under $\mathrm{HNO}_{3}$-based pickling conditions. This was largely due to $\mathrm{NH}_{4} \mathrm{HF}_{2}$, which means that the $\mathrm{F}$ compounds were formed on the surface only after $\mathrm{HNO}_{3}$-based pickling. XRD analysis (Figure 7) indicated that the Fe of the base material was only detected in the specimens that underwent conventional pickling and $\mathrm{HCl}$-based pickling. However, various components were detected in the specimen that underwent $\mathrm{HNO}_{3}$-based pickling. The products formed under $\mathrm{HNO}_{3}$ based pickling were $\left(\mathrm{NH}_{4}\right) \mathrm{FeF}_{5} \cdot \mathrm{H}_{2} \mathrm{O}, \mathrm{FeSiF}_{6} \cdot 6 \mathrm{H}_{2} \mathrm{O}, \mathrm{FeF}_{2}$, and/or $\mathrm{FeF}_{3}$. The products were produced by the following reactions $[13,14]$ :

$$
\begin{gathered}
\mathrm{Fe}_{2} \mathrm{O}_{3}+5 \mathrm{NH}_{4} \mathrm{HF}_{2} \rightarrow 2\left(\mathrm{NH}_{4}\right)_{2} \mathrm{FeF}_{5}+3 \mathrm{H}_{2} \mathrm{O}+\mathrm{NH}_{3} \uparrow \\
\mathrm{Si}+2 \mathrm{H}^{+}+2 \mathrm{~F}^{-}+4 \mathrm{HF} \rightarrow \mathrm{H}_{2} \mathrm{SiF}_{6} \cdot 6 \mathrm{H}_{2} \mathrm{O}+2 \mathrm{H}_{2} \uparrow \\
\mathrm{Fe}^{2+}+2 \mathrm{~F}^{-} \rightarrow \mathrm{FeF}_{2} \\
\mathrm{FeF}_{2}+\mathrm{H}_{2} \mathrm{SiF}_{6} \rightarrow \mathrm{FeSiF}_{6}+2 \mathrm{HF}
\end{gathered}
$$


(a)

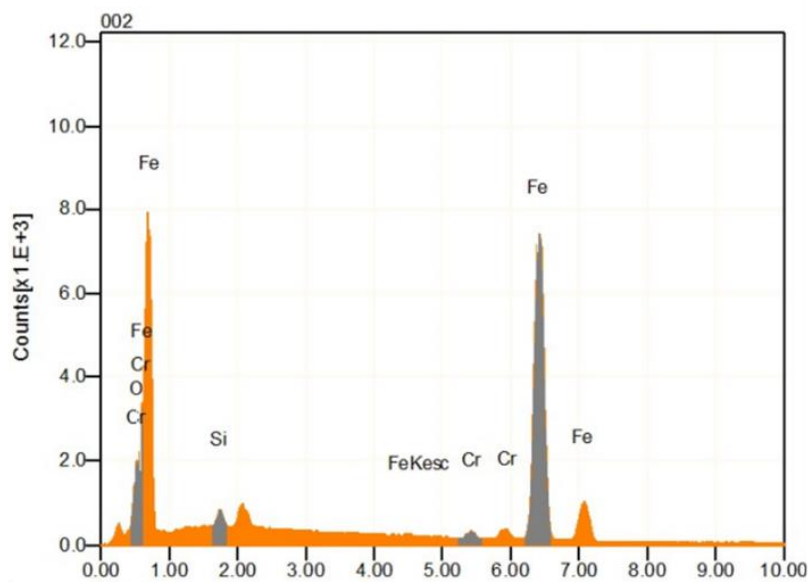

(b)

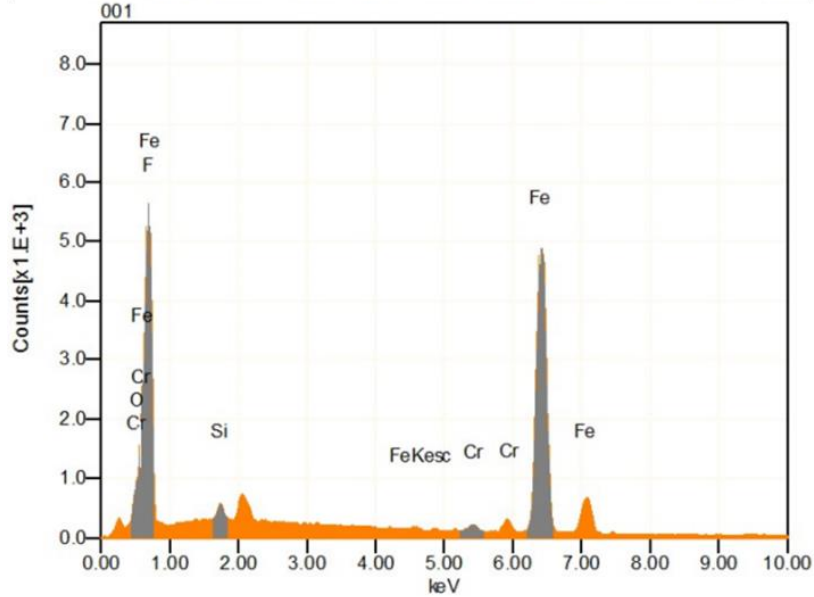

Figure 5. EDS analysis of the 1.0Si steel surface after pickling under (a) a HCl-based condition and (b) a $\mathrm{HNO}_{3}$-based condition.

(a)

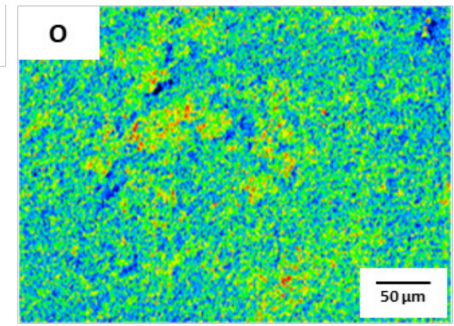

(b)

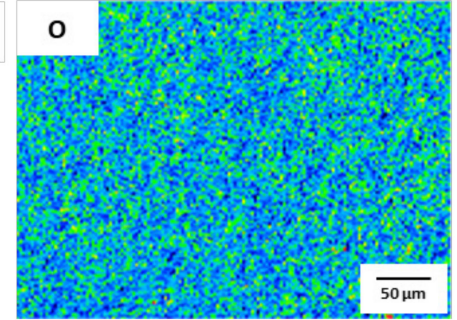

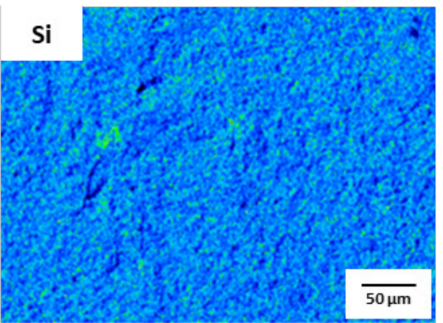

\section{Si}

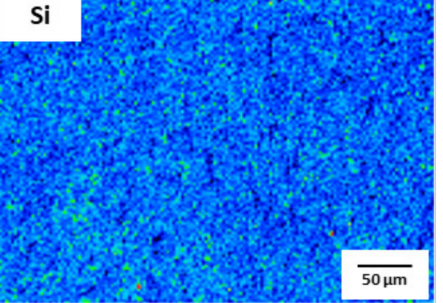

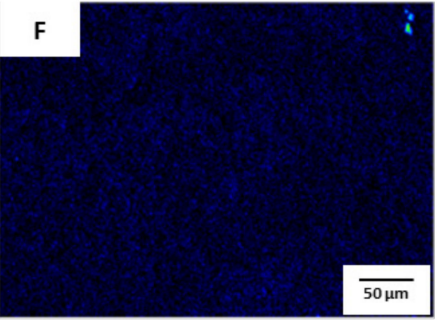

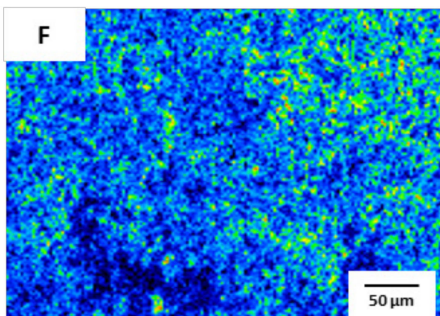

High

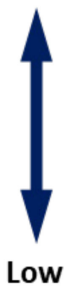

Figure 6. EPMA analysis of the 1.0Si steel surface after pickling under (a) a $\mathrm{HCl}$-based condition and (b) a $\mathrm{HNO}_{3}$-based condition. 


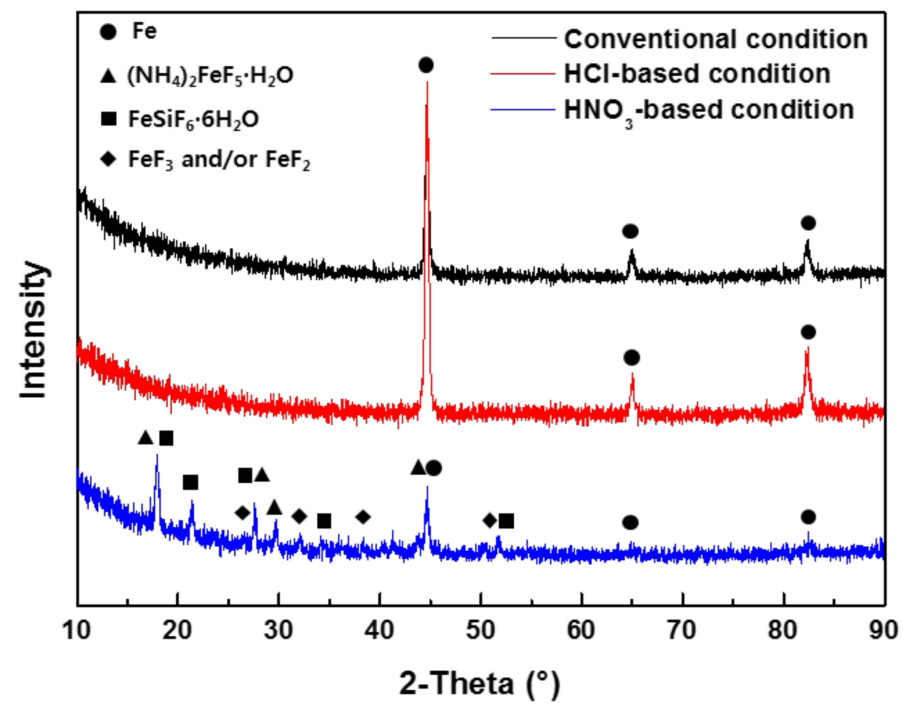

Figure 7. XRD analysis of the 1.0Si steel surface after pickling.

Table 4. EDS results of the 1.0Si steel surface after pickling.

\begin{tabular}{cccccc}
\hline Parameter & Fe & O & Si & F & Cr \\
\hline $\begin{array}{c}\text { HCl-based } \\
\text { pickling condition (\%) }\end{array}$ & 94.13 & 3.77 & 0.85 & - & 1.25 \\
$\begin{array}{c}\text { HNO }_{\text {3 }} \text {-based } \\
\text { pickling condition (\%) }\end{array}$ & 92.25 & 1.98 & 0.85 & 3.56 & 1.36 \\
\hline
\end{tabular}

In the $\mathrm{HNO}_{3} / \mathrm{HF}$ system, $\mathrm{FeF}_{3} \cdot 3 \mathrm{H}_{2} \mathrm{O}$ was in a stable phase at low $\mathrm{pH}(\mathrm{pH}<3.16)$ and then transformed into $\mathrm{FeF}_{2}$ and $\mathrm{FeF}_{3}$ at higher $\mathrm{pH}[15,16]$. However, in the $\mathrm{HCl} / \mathrm{HF}$ system, $\mathrm{HCl}$ made insoluble ferric fluoride, preventing the formation of fluoride precipitates [17].

\subsection{Phosphatability}

Figure 8 shows EPMA images of a cross section of 1.0Si steel on which a phosphate coating was formed. Under conventional pickling conditions, phosphate crystals were rarely formed; under $\mathrm{HCl}$-based pickling, the areas where phosphate crystals did not form were sparse. However, under $\mathrm{HNO}_{3}$-based pickling, the phosphate crystals were uniformly formed. As shown in Figures 5 and 6, the F compounds found after pickling were not observed after the phosphate treatment. Therefore, the F compounds were involved in the formation of phosphate crystals. In other words, the F compounds introduced by pickling had a positive effect on the phosphatability of the steel.

The phosphate treatment of AHSS was performed with various concentrations of hydrochloric acid $(\mathrm{HCl})$ and nitric acid $\left(\mathrm{HNO}_{3}\right)$. SEM images of the surface after phosphate treatment are shown in Figures 9-12. When pickling was performed with $\mathrm{NH}_{4} \mathrm{HF}_{2}$, more phosphate crystals were formed compared to with the conventional pickling. However, as shown in Figures 9 and 10, phosphate crystals were not formed in many regions. Figures 11 and 12 show significantly fewer areas where phosphate crystals were not formed compared to Figures 9 and 10. Furthermore, the phosphate crystals became finer after pickling with a $\mathrm{HNO}_{3}$-based solution than with a $\mathrm{HCl}$-based solution. In addition, phosphate crystals were formed more uniformly on the surface of 1.0Si steel in both the $\mathrm{HCl}$ - and $\mathrm{HNO}_{3}$-based solutions compared to those formed on 0.4Si steel. 


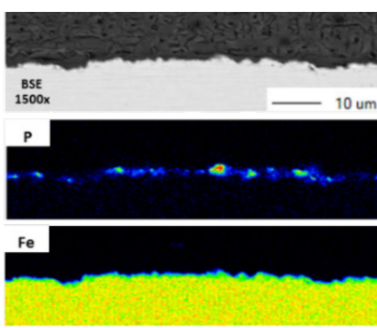

(a)

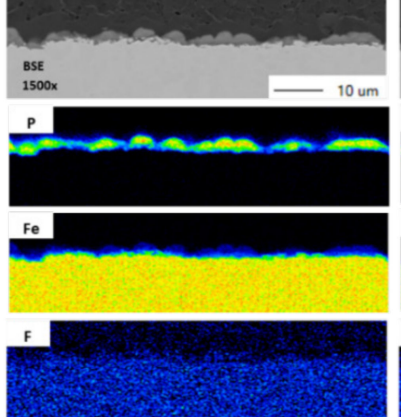

(b)

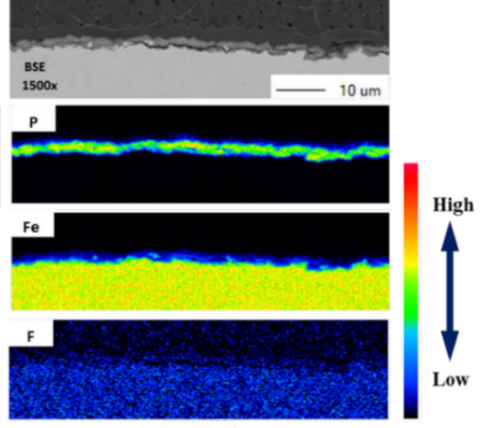

(c)

Figure 8. EPMA images of cross sections of 1.0Si steel formed with phosphate coating using (a) conventional conditions, (b) a $\mathrm{HCl}$-based condition, and (c) a $\mathrm{HNO}_{3}$-based condition.
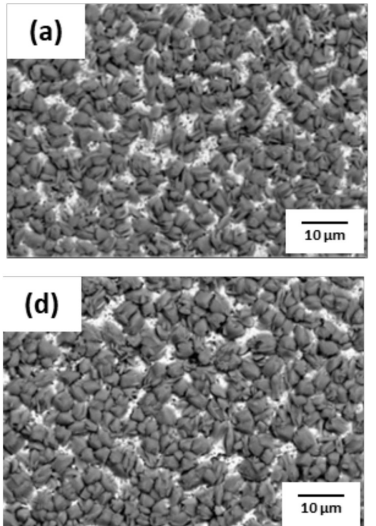
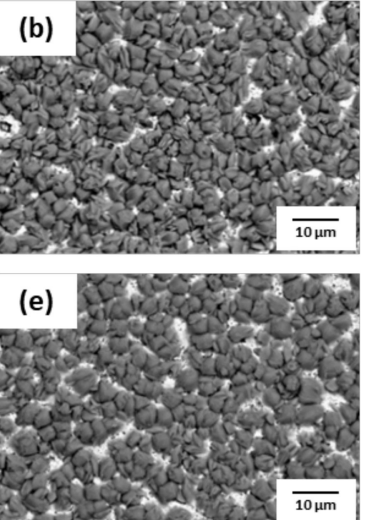
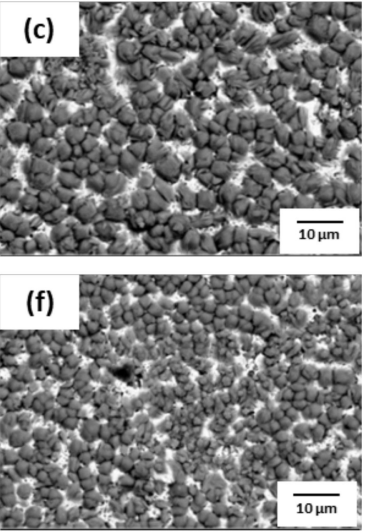

Figure 9. Surface SEM images of 1.0Si steel after phosphate treatment under HCl-based pickling condition with $\mathrm{HCl}$ concentration of (a) $5.5 \%$, (b) $8 \%$, (c) $10.5 \%$, (d) $13 \%$, (e) $15.5 \%$, and (f) $18 \%$.
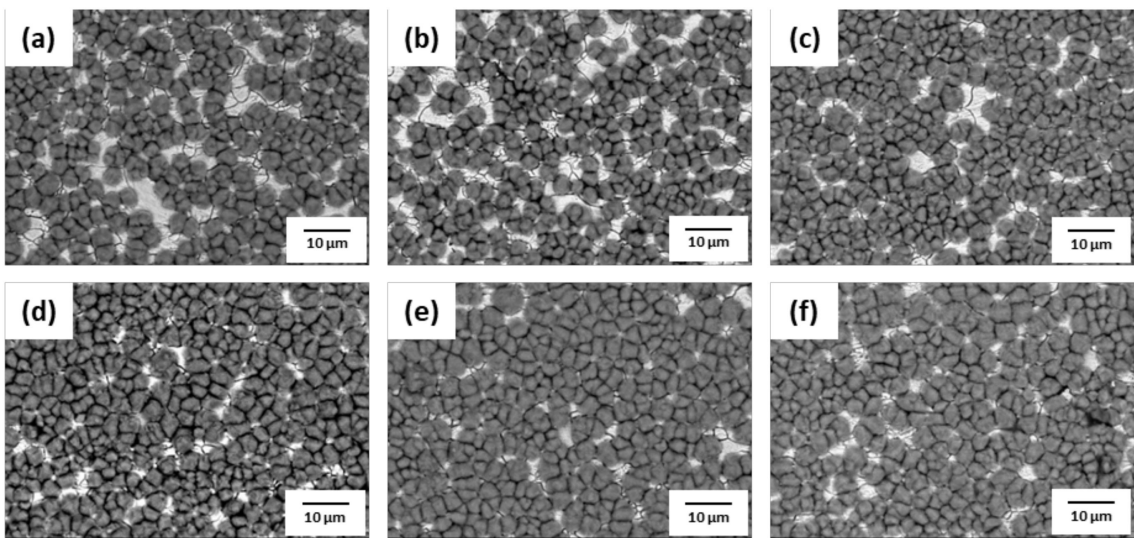

Figure 10. Surface SEM image of 0.4Si steel after phosphate treatment under HCl-based pickling condition with $\mathrm{HCl}$ concentration of (a) $5.5 \%$, (b) $8 \%$, (c) $10.5 \%$, (d) $13 \%$, (e) $15.5 \%$, and (f) $18 \%$. 

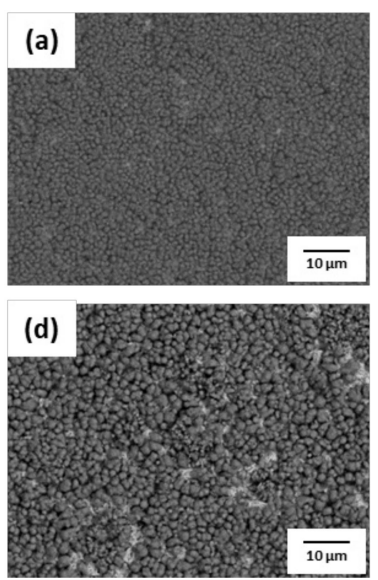
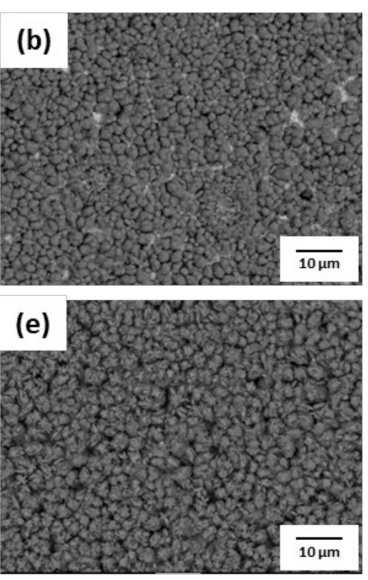
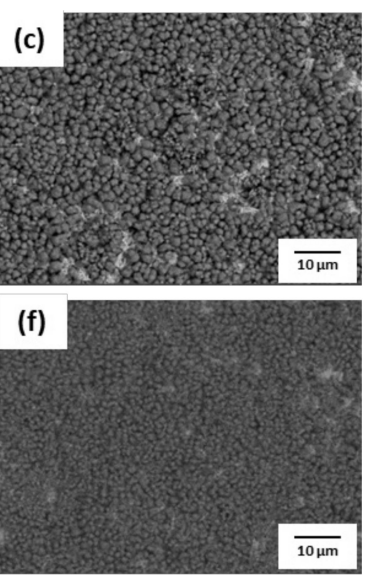

Figure 11. Surface SEM images of 1.0Si steel after phosphate treatment under $\mathrm{HNO}_{3}$-based pickling condition with $\mathrm{HNO}_{3}$ concentration of (a) $5.5 \%$, (b) $8 \%$, (c) $10.5 \%$, (d) $13 \%$, (e) $15.5 \%$, and (f) $18 \%$.
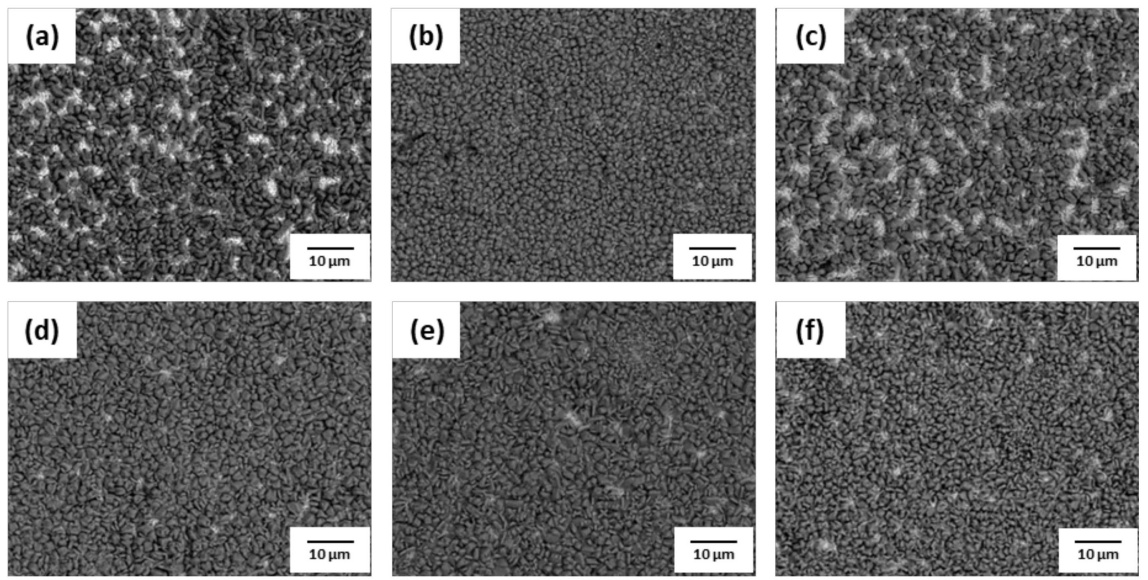

Figure 12. Surface SEM images of $0.4 \mathrm{Si}$ steel after phosphate treatment under $\mathrm{HNO}_{3}$-based pickling condition with $\mathrm{HNO}_{3}$ concentration of (a) $5.5 \%$, (b) $8 \%$, (c) $10.5 \%$, (d) $13 \%$, (e) $15.5 \%$, and (f) $18 \%$.

Figure 13 shows the coating coverage and coating weight as a function of the $\mathrm{HCl}$ and $\mathrm{HNO}_{3}$ concentrations. Figure 13a shows that the coating coverage of 1.0Si steel decreased as the concentration of hydrochloric acid increased, whereas the coating coverage of $0.4 \mathrm{Si}$ steel increased as the concentration of hydrochloric acid increased. In addition, the coating coverage of both steels did not meet the phosphate quality requirements ( $95 \%$ or more) for automobiles. In the case of the coating weight, as the concentration of $\mathrm{HCl}$ increased, the coating weight of both $1.0 \mathrm{Si}$ and $0.4 \mathrm{Si}$ steel decreased. However, the phosphate quality requirement $\left(2 \mathrm{~g} / \mathrm{m}^{2}\right.$ or more $)$ for automobiles was satisfied at all $\mathrm{HCl}$ concentrations except for $18 \%$. As shown in Figure 13b, the coating coverage was not uniform at $\mathrm{HNO}_{3}$ concentration below $10.5 \%$, whereas $\mathrm{HNO}_{3}$ concentration of $13 \%$ or more showed excellent coating coverage of at least $98 \%$. $\mathrm{A} \mathrm{HNO}_{3}$ concentration of $8 \%$ was sufficient to achieve the desired coating coverage for $0.4 \mathrm{Si}$ steel. However, $1.0 \mathrm{Si}$ steel does not satisfy the desired coating coverage. Therefore, at least $13 \%$ of $\mathrm{HNO}_{3}$ was required to meet the desired coating coverage. Furthermore, the coating weight was excellent at all concentrations. 

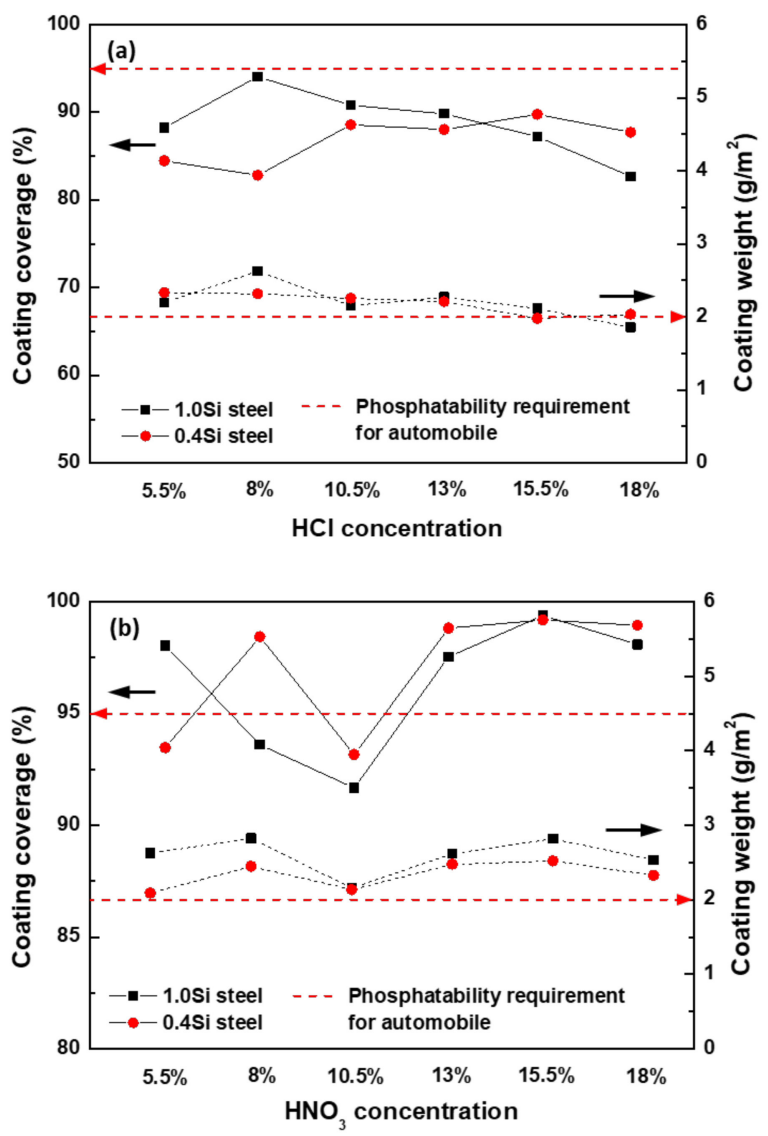

Figure 13. Coating coverage and coating weight vs. the inorganic acid concentration under (a) $\mathrm{HCl}$ based condition and (b) $\mathrm{HNO}_{3}$-based condition.

\subsection{Electrochemical Imedance Spectroscopy}

The results of EIS in the form of a Bode plot are shown in Figure 14. In the Bode plot, the low-frequency region is related to the surface film and the metal/surface interface, whereas the high-frequency region is attributed to the defects on the metal surface [18-20]. In the low-frequency region, the impedance $(|\mathrm{Z}|)$ values of $0.4 \mathrm{Si}$ steel were higher than those of 1.0Si steel. However, there was no significant difference in $|Z|$ value with the use of different types of inorganic acids in both steels. The phase angle maxima and shoulder widths of the phase angles also showed the same trends as the $|\mathrm{Z}|$ values. The results of $|\mathrm{Z}|$ values and phase angle data indicate that the corrosion resistance of $0.4 \mathrm{Si}$ steel was superior to that of 1.0Si steel. However, there was no relationship between the concentration of inorganic acid and the $|\mathrm{Z}|$ values. Furthermore, improvement in corrosion resistance from the phosphate coating was not significant due to the short phosphating time used in the experiment. In general, the phosphate coating improves the corrosion resistance of a substrate. However, noticeable improvement in corrosion resistance is not observed during the stage of induction and commencement of film growth, which are the stages from the start of the phosphate treatment to $3 \mathrm{~min}[21,22]$. Since the phosphating time in this study was within $2 \mathrm{~min}$, the EIS results indicate that phosphate crystals had not sufficiently formed to be able to improve corrosion resistance for both types of inorganic acid. The phosphating industry generally uses coating weight and coverage as part of quality control, but coating weight and coverage do not have a direct relationship to corrosion resistance [21]. Therefore, the low correlation between coating weight, coverage, and the $|\mathrm{Z}|$ values was due to various factors, such as thickness and structure homogeneity. 

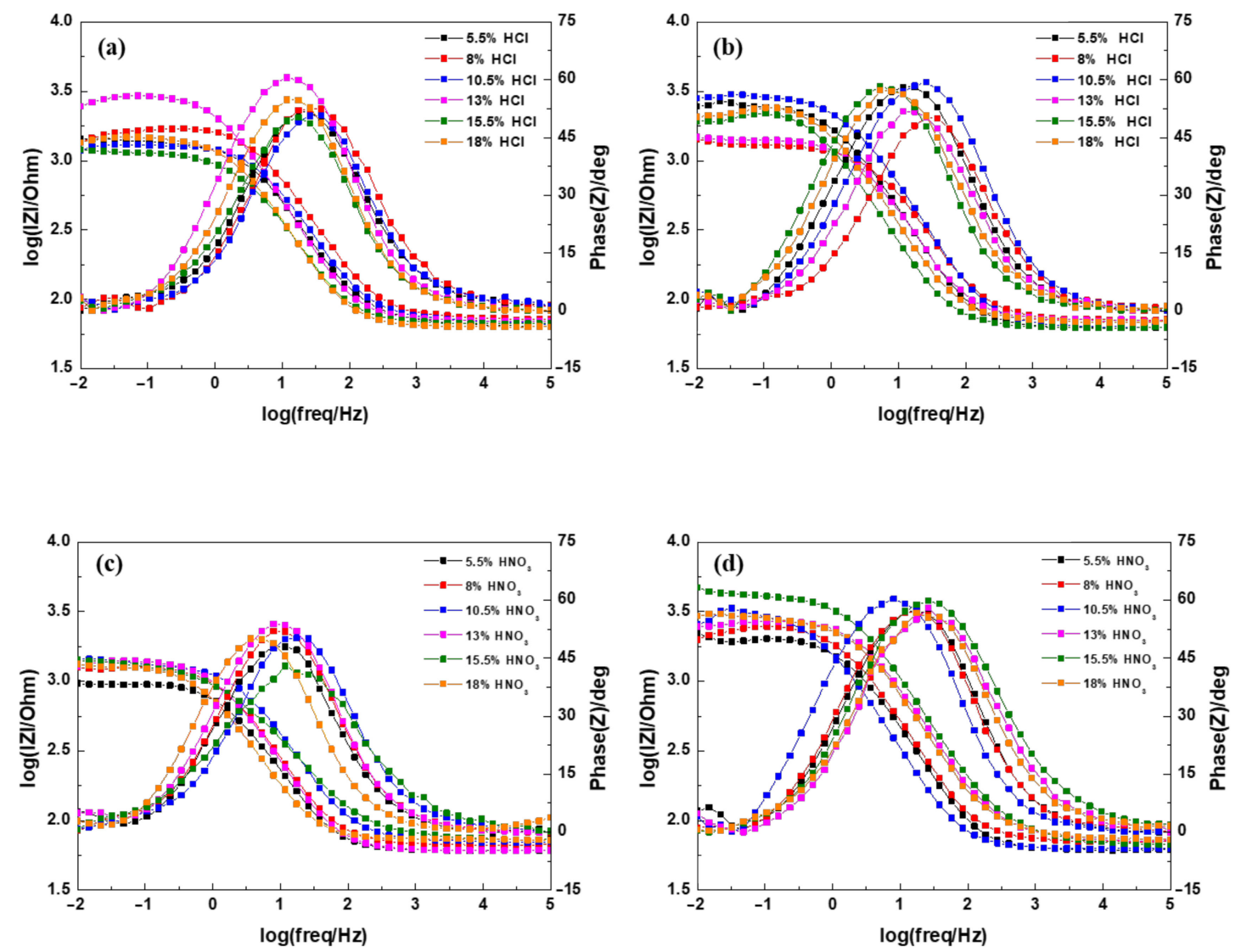

Figure 14. Bode impedance plots of electrochemical impedance spectroscopy (EIS) data of (a,c) $1.0 \mathrm{Si}$ steel and (b,d) $0.4 \mathrm{Si}$ steel in SAE solution.

The equivalent electric circuit model used to determine the optimized value for resistance and capacitance parameters is shown in Figure 15, and the corresponding EIS results are listed in Table $5 . R_{S}$ is the solution resistance, CPE1 and $R_{\text {coat }}$ are the capacitance and resistance of the phosphate coating layer, CPE2 is the double layer capacitance, $R_{\mathrm{ct}}$ is the charge transfer resistance, $Q_{\text {coat }}$ and $Q_{\mathrm{ct}}$ are coating's capacitance and charge transfer capacitance, and $\mathrm{n}$ is an empirical exponent $(0 \leq \mathrm{n} \leq 1)$ measuring the deviation from the behavior of the ideal electric capacity. Figure 16 shows the variation of coating resistance $\left(R_{\text {coat }}\right)$ from EIS measurement results as a function of inorganic acid concentration.

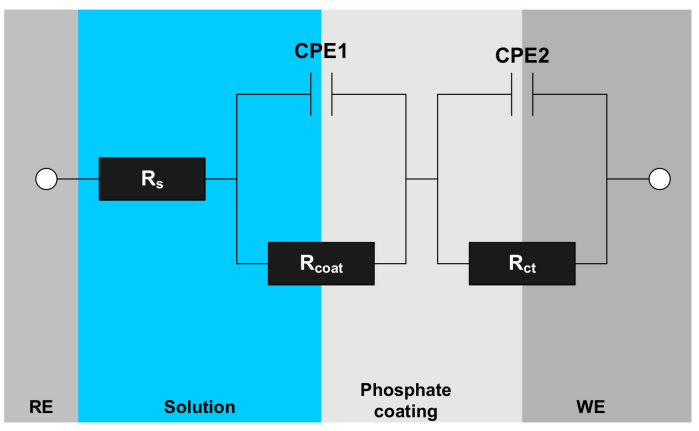

Figure 15. Equivalent circuit for phosphate coated steel in SAE solution. $R_{s}$ is the solution resistance; $\mathrm{CPE} 1$ and $\mathrm{R}_{\text {coat }}$ are the capacitance and resistance of the phosphate coating layer; CPE2 is the double layer capacitance; $R_{c t}$ is the charge transfer resistance; WE and RE are working electrode and reference electrode. 
Table 5. Parameters from electrochemical impedance spectroscopy measurements.

\begin{tabular}{|c|c|c|c|c|c|c|c|c|c|}
\hline \multirow[b]{2}{*}{ Acid } & \multirow[b]{2}{*}{ Steel } & \multirow[b]{2}{*}{ Concentration } & \multirow{2}{*}{$\begin{array}{c}R_{s} \\
\left(\Omega \cdot \mathrm{cm}^{2}\right)\end{array}$} & \multicolumn{2}{|c|}{ CPE1 } & \multirow{2}{*}{$\begin{array}{c}R_{\text {coat }} \\
\left(\Omega \cdot \mathrm{cm}^{2}\right)\end{array}$} & \multicolumn{2}{|c|}{ CPE2 } & \multirow{2}{*}{$\begin{array}{c}R_{\mathrm{ct}} \\
\left(\Omega \cdot \mathrm{cm}^{2}\right)\end{array}$} \\
\hline & & & & $\begin{array}{c}Q_{\text {coat }} \\
\left(\mu \mathrm{F} / \mathrm{cm}^{2}\right)\end{array}$ & $\mathbf{n}_{1}$ & & $\begin{array}{c}Q_{c t} \\
\left(\mu \mathrm{F} / \mathrm{cm}^{2}\right)\end{array}$ & $\mathbf{n}_{2}$ & \\
\hline \multirow{12}{*}{$\mathrm{HCl}$} & \multirow{6}{*}{$1.0 \mathrm{Si}$} & $5.5 \%$ & 62.98 & 56 & 0.8 & 1183 & 45.5 & 0.8 & 279.8 \\
\hline & & $8 \%$ & 72.35 & 149 & 0.7301 & 358.2 & 42.4 & 0.9004 & 1285 \\
\hline & & $10.5 \%$ & 63.58 & 178.3 & 0.5432 & 89.6 & 46.6 & 0.9395 & 1223 \\
\hline & & $13 \%$ & 70.29 & 189.3 & 1 & 1083 & 64.7 & 0.9535 & 1777 \\
\hline & & $15.5 \%$ & 67.04 & 108 & 0.8995 & 430.8 & 243 & 0.7957 & 673.2 \\
\hline & & $18 \%$ & 63.41 & 208 & 0.975 & 140.6 & 104 & 0.8421 & 1,287 \\
\hline & \multirow{6}{*}{$0.4 \mathrm{Si}$} & $5.5 \%$ & 62.37 & 75 & 0.8419 & 1504 & 265 & 1 & 918.9 \\
\hline & & $8 \%$ & 70.87 & 8990 & 0.6406 & 145.9 & 49.1 & 0.8305 & 1168 \\
\hline & & $10.5 \%$ & 63.16 & 207.9 & 0.9996 & 940.4 & 45.8 & 0.8414 & 1878 \\
\hline & & $13 \%$ & 70.72 & 981 & 1 & 179.4 & 70.6 & 0.8408 & 1186 \\
\hline & & $15.5 \%$ & 62.67 & 179 & 0.8284 & 775.1 & 220 & 1 & 1320 \\
\hline & & $18 \%$ & 69.29 & 134 & 0.8182 & 819.5 & 153 & 1 & 1413 \\
\hline \multirow{12}{*}{$\mathrm{HNO}_{3}$} & \multirow{6}{*}{$1.0 \mathrm{Si}$} & $5.5 \%$ & 60.91 & 476 & 1 & 367.8 & 157 & 0.8468 & 528.2 \\
\hline & & $8 \%$ & 66.97 & 120 & 0.8452 & 967.2 & 910 & 0.98 & 235.9 \\
\hline & & $10.5 \%$ & 70.41 & 74.2 & 0.8295 & 1227 & 14,200 & 0.9539 & 138.1 \\
\hline & & $13 \%$ & 61.01 & 186 & 0.8669 & 1059 & 250 & 0.8649 & 301.2 \\
\hline & & $15.5 \%$ & 72.76 & 266 & 0.6565 & 1066 & 204 & 0.8387 & 272.2 \\
\hline & & $18 \%$ & 73.47 & 300.1 & 0.8455 & 4300 & 397.7 & 0.9307 & 766.8 \\
\hline & \multirow{6}{*}{$0.4 \mathrm{Si}$} & $5.5 \%$ & 61.46 & 72.2 & 0.8527 & 1015 & 169 & 0.982 & 945.6 \\
\hline & & $8 \%$ & 70.7 & 209 & 1 & 892.6 & 65 & 0.8414 & 1525 \\
\hline & & $10.5 \%$ & 62.75 & 345 & 1 & 1332 & 108 & 0.8473 & 1680 \\
\hline & & $13 \%$ & 72.12 & 48.7 & 0.9522 & 1564 & 66.2 & 0.7682 & 1036 \\
\hline & & $15.5 \%$ & 65.98 & 29.4 & 0.8391 & 3812 & 2085 & 0.4284 & 690.9 \\
\hline & & $18 \%$ & 73.74 & 38.9 & 0.8746 & 2000 & 426 & 0.635 & 932.9 \\
\hline
\end{tabular}

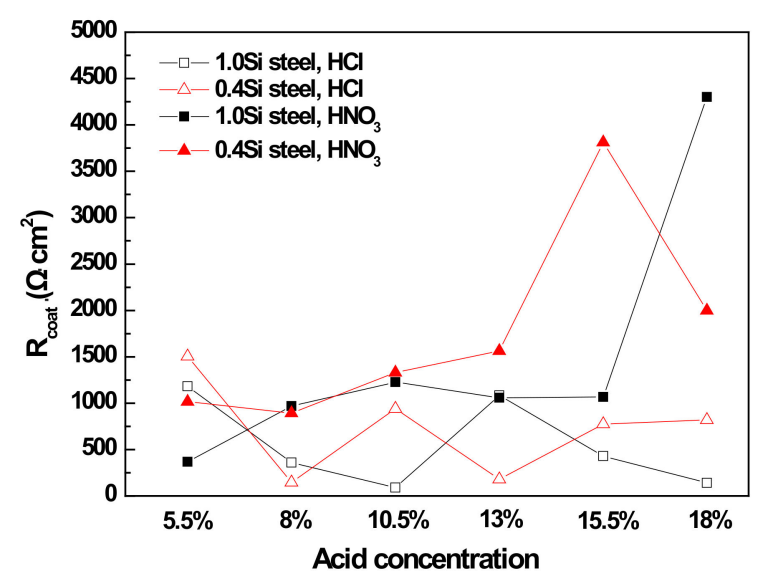

Figure 16. Variation of coating resistance $\left(\mathrm{R}_{\text {coat }}\right)$ from EIS analysis vs. inorganic acid concentration.

Unlike the $|\mathrm{Z}|$ values, there was no significant difference between the $\mathrm{R}_{\text {coat }}$ of $1.0 \mathrm{Si}$ and $0.4 \mathrm{Si}$ steel. However, the $\mathrm{R}_{\text {coat }}$ under $\mathrm{HNO}_{3}$-based pickling conditions was higher than that under $\mathrm{HCl}$-based pickling condition in both steels, and $\mathrm{R}_{\text {coat }}$ increased significantly as the concentration increased under $\mathrm{HNO}_{3}$-based pickling conditions. This result is consistent with the coating coverage data shown in Figure 6 . $R_{\text {coat }}$ was affected more by coating coverage than by coating weight.

\section{4. $\mathrm{pH}$ Measurement}

In general, during the early stages of phosphate treatment, the reaction of iron or iron oxide with hydrogen ions increases locally with the $\mathrm{pH}$ at the metal surface, which promotes the nucleation of phosphate crystals [8]. The effects of iron oxides and $\mathrm{F}$ compounds 
generated under $\mathrm{HNO}_{3}$-based pickling on the $\mathrm{pH}$ of the phosphate solution, are shown in Figure 17. The $\mathrm{pH}$ of the bulk solution did not change significantly when iron and iron oxides reacted with the phosphate solution. However, with $\mathrm{F}$ compounds, the $\mathrm{pH}$ of the bulk solution increased from 3.3 to 3.6 after reacting with the phosphate solution. Among $\mathrm{F}$ compounds, $\mathrm{FeF}_{3}$ has a $\mathrm{pH}$ of 3.5-4.0 when dissolved in water (Equation (6)) [23]. Therefore, this $\mathrm{F}$ compound could have increased the $\mathrm{pH}$ of the phosphate solution by reacting with water. This increase in the $\mathrm{pH}$ of the phosphate solution indicates that the $\mathrm{F}$ compounds had a positive effect on the phosphatability of the steel because F compounds act as an accelerator for consumption of hydrogen ions.

$$
\mathrm{FeF}_{3}+3 \mathrm{H}_{2} \mathrm{O} \rightarrow \mathrm{Fe}(\mathrm{OH})_{3}+3 \mathrm{HF}
$$

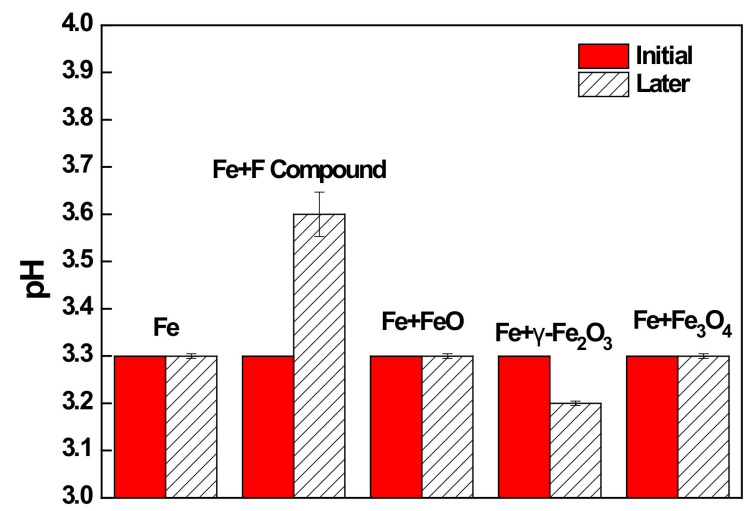

Figure 17. $\mathrm{pH}$ variation of phosphate solution before and after the addition of various iron oxides and $\mathrm{F}$ compounds.

\subsection{Surface Roughness Measurement}

The correlation between the surface roughness after pickling and the phosphatability of the steel is shown in Figure 18. The surface roughness was higher under a $\mathrm{HNO}_{3}$-based pickling condition than under a $\mathrm{HCl}$-based pickling condition. This result is due to $\mathrm{NO}_{3}{ }^{-}$ ions acting as oxidizing agents; thus, the corrosiveness of $\mathrm{HNO}_{3}$ is higher than that of $\mathrm{HCl}$ [24]. Generally, a higher surface roughness is associated with a higher coating weight and the formation of finer crystals; a level of $0.76-1.77 \mu \mathrm{m}$ was reported to be the most suitable average roughness ( $\mathrm{Ra})[21,25]$. In other words, the phosphatability was better with $\mathrm{HNO}_{3}$-based pickling than with $\mathrm{HCl}$-based pickling due to the surface roughness. However, the phosphatability did not have a significant correlation with surface roughness.
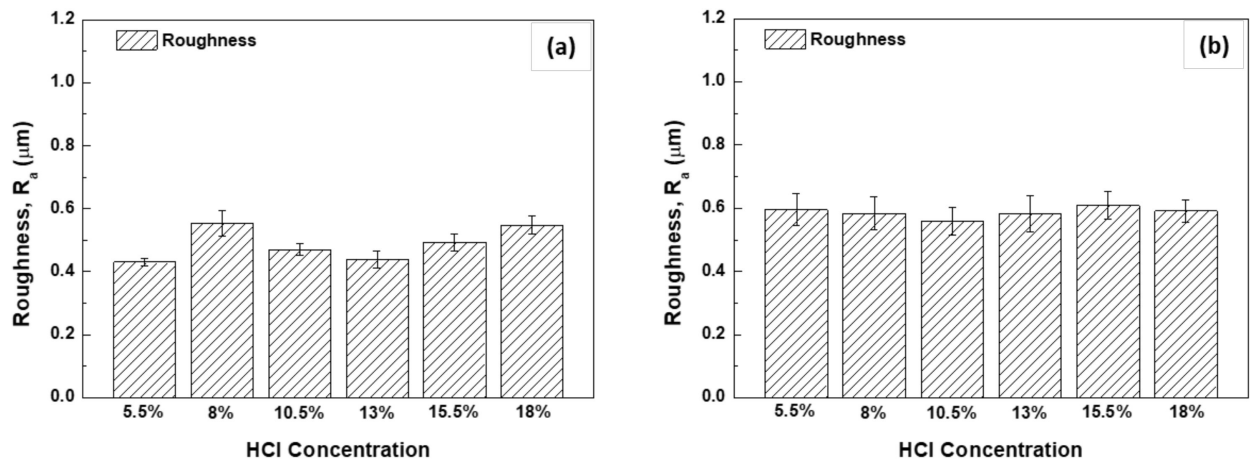

Figure 18. Cont. 

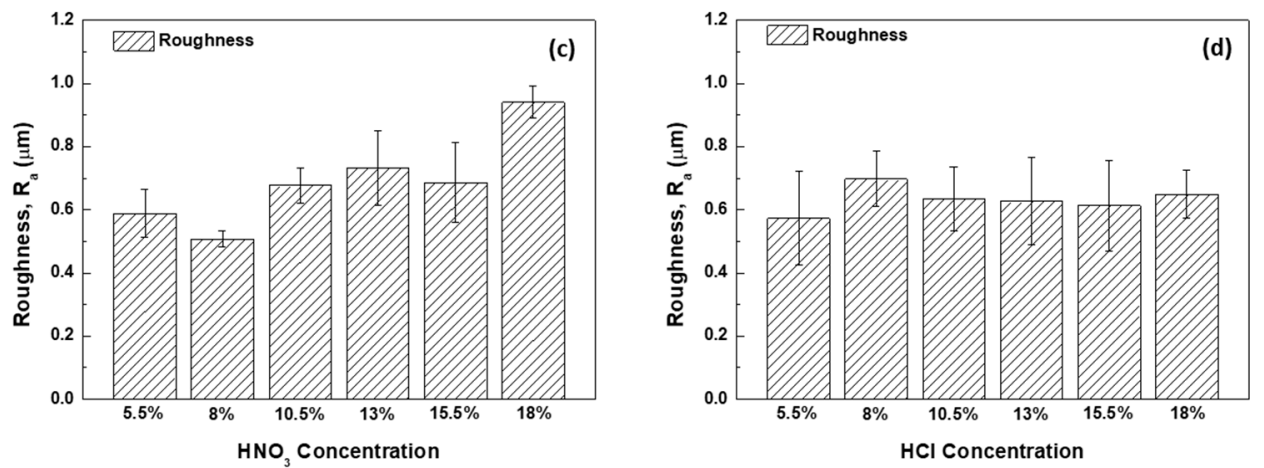

Figure 18. Correlation between surface roughness and phosphatability; $(\mathbf{a}, \mathbf{c}) 1.0 \mathrm{Si}$ steel and $(\mathbf{b}, \mathbf{d}) 0.4 \mathrm{Si}$ steel.

\section{Conclusions}

In this study, the optimum pickling conditions to improve the phosphatability of AHSS were investigated using various types of surface analysis and EIS. The conclusions based on our investigation are as follows:

- With $\mathrm{HNO}_{3}$-based pickling solutions, the phosphatability improved remarkably at $\mathrm{HNO}_{3}$ concentrations higher than $13 \%$ for both steels. Furthermore, the phosphate crystals became finer after pickling with a $\mathrm{HNO}_{3}$-based solution compared to those with a HCl-based solution.

- $\mathrm{SiO}_{2}$ was noticeably removed by a pickling solution with $\mathrm{NH}_{4} \mathrm{HF}_{2}$.

- The corrosion resistance of phosphate-treated AHSS was higher using a $\mathrm{HNO}_{3}$-based pickling condition compared to a HCl-based pickling condition.

- With $\mathrm{HNO}_{3}$-based pickling solutions, F compounds, which are involved in the phosphate treatment process, formed on the surface of the AHSS. The F compounds reacted with the phosphate solution to increase the $\mathrm{pH}$ of the phosphate solution, thereby greatly improving the phosphatability of AHSS.

- The phosphatability was better under $\mathrm{HNO}_{3}$-based pickling conditions than under $\mathrm{HCl}$-based pickling conditions due to the increased surface roughness.

Author Contributions: Conceptualization, S.C. and Y.-H.Y.; methodology, J.-G.K.; software, S.-J.K. and J.-S.Y.; validation, Y.-H.Y., J.-C.P. and J.-G.K.; formal analysis, S.C.; investigation, S.C. and S.-J.K.; resources, J.-C.P. and Y.-H.Y.; data curation, S.C.; writing—original draft preparation, S.C.; writingreview and editing, S.C., S.-J.K., J.-S.Y., Y.-H.Y. and J.-G.K.; visualization, S.C.; supervision, J.-G.K.; project administration, Y.-H.Y. and J.-G.K.; funding acquisition, J.-G.K. All authors have read and agreed to the published version of the manuscript.

Funding: This research was funded by POSCO, grant number $2017 Z 068$.

Institutional Review Board Statement: Not applicable.

Informed Consent Statement: Not applicable.

Data Availability Statement: Data sharing is not applicable to this article.

Conflicts of Interest: The authors declare no conflict of interest.

\section{References}

1. Kulekei, M.M. Magnesium and its alloys applications in automotive industry. Int. J. Adv. Manuf. Technol. 2008, 39, 851-865. [CrossRef]

2. Tisza, M.; Czinege, I. Comparative study of the application of steels and aluminum in lightweight production of automotive parts. Int. J. Lightweight Mater. Manuf. 2018, 1, 229-238.

3. Machado, J.J.M.; Nunes, P.D.P.; Marques, E.A.S.; Da Silva, L.F.M. Adhesive joints using aluminium and CFRP substrates tested at low and high temperature under quasi-static and impact conditions for the automotive industry. Compos. Part B 2019, 158, 102-116. [CrossRef] 
4. Kang, J.; Rao, H.; Zhang, R.; Avery, K.; Su, X. Tensile and fatigue behavior of self-piercing revets of CFRP to aluminium for automotive application. IOP Conf. Ser. Mater. Sci. Eng. 2016, 137, 12-25. [CrossRef]

5. Matheis, R.; Eckstein, L. Aluminium-carbon fibre-reinforced polymer hybrid crash management system incorporating braided tubes. Int. J. Automot. Compos. 2016, 2, 330-355. [CrossRef]

6. Fathyunes, L.; Azadbeh, M.; Tanhaei, M.; Sheykholeslami, S.O.R. Study on an elaborated method to improve corrosion resistance of zinc phosphate coating. J. Coat. Technol. Res. 2017, 14, 709-720. [CrossRef]

7. Kathavate, V.S.; Pawar, D.N.; Bagal, N.S.; Deshpande, P.P. Role of nano ZnO particles in the electrodeposition and growth mechanism of phosphate coatings for enhancing the anti-corrosive performance of low carbon steel in $3.5 \% \mathrm{NaCl}$ aqueous solution. J. Alloys Compd. 2020, 823, 153812. [CrossRef]

8. Tegehall, P.-E.; Vannerberg, N.G. Nucleation and formation of zinc phosphate conversion coating on cold-rolled steel. Corros. Sci. 1991, 32, 635-652. [CrossRef]

9. Nomura, M.; Hashimoto, I.; Kamura, M.; Kozuma, S. Development of high strength cold-rolled steel-sheets with excellent phosphatability. Kobeco Technol. Rev. 2007, 28, 44-48.

10. Jung, B.H.; Lee, K. Method and Device for Pickling Ultra-High Strength Steel Sheet. Kr. Patent KR101696117B1, 13 January 2017.

11. Park, H.K.; Nho, H.S.; Kwak, S.J.; Park, S.H. Method for Pickling Hot Rolled Steel Sheet Having Advanced High Strength. Kr. Patent KR20120074135A, 5 July 2012.

12. Lee, C.T. Non-HF type etching solution for slimming of flat panel display glass. Appl. Chem. Eng. 2016, 27, 101-109. [CrossRef]

13. Kraydenko, R.I.; Dyachenko, A.N.; Malyutin, L.N.; Petlin, I.V. The mechanism for production of beryllium fluoride from the product of ammonium fluoride processing of beryllium-containing raw material. IOP Conf. Ser. Mater. Sci. Eng. 2016, 135, 12-21. [CrossRef]

14. Pastushenko, A.; Lysenko, V. Electrochemical synthesis of luminescent ferrous fluorosilicate hexahydrate $\left(\mathrm{FeSiF}_{6} \cdot 6 \mathrm{H}_{2} \mathrm{O}\right)$ nanopowders. RSC Adv. 2016, 6, 8093-8095. [CrossRef]

15. Reddy, R.G.; Wang, S.; Chen, B. Solubility of iron in spent pickling solutions. Min. Met. Explor. 1993, 10, 102-107. [CrossRef]

16. Sartor, M.; Buchloh, D.; Rogener, F.; Reichardt, T. Removal of iron fluorides from spent mixed acid pickling solutions by colling precipitation at extreme temperatures. Chem. Eng. J. 2009, 153, 50-55. [CrossRef]

17. Park, H.S.; Cho, J.H.; Jung, J.H.; Duy, P.P.; Le, A.H.T.; Yi, J. A review of wet chemical etching of glass in hydrofluoric acid based solution for thin film silicon solar cell application. Curr. Phot. Res. 2017, 5, 75-82.

18. Kim, K.H.; Lee, S.H.; Nguyen, D.N.; Kim, J.G. Effect of cobalt on the corrosion resistance of low alloy steel in sulfuric acid solution. Corros. Sci. 2011, 53, 3576-3587. [CrossRef]

19. Hong, M.S.; Kim, S.H.; Im, S.Y.; Kim, J.G. Effect of Ascorbic acid on the pitting resistance of 316L stainless steel in synthetic tap water. Met. Mater. Int. 2016, 22, 621-629. [CrossRef]

20. Kissi, M.; Bouklah, M.; Hammouti, B.; Benkaddour, M. Establishment of equivalent circuits from electrochemical impedance spectroscopy study of corrosion inhibition of steel by pyrazine in sulphuric acidic solution. Appl. Surf. Sci. 2006, 252, $4190-4197$. [CrossRef]

21. Sankara Narayanan, T.S.N. Surface pretreatment by phosphate conversion coatings-A review. Rev. Adv. Mater. Sci. 2005, 9, 130-177.

22. Asadi, V.; Danaee, I.; Eskandari, H. The effect of immersion time and immersion temperature on the corrosion behavior of zinc phosphate conversion coatings on carbon steel. Mater. Res. 2015, 18, 706-713. [CrossRef]

23. Jones, D.A. Principles and Prevention of Corrosion, 2nd ed.; Prentice Hall, Inc.: Upper Saddle River, NJ, USA, 1996.

24. Kim, H.J. Variation of phosphatability with chemical composition and surface roughness of steel sheet. Surf. Eng. 1998, 14, 265-267. [CrossRef]

25. Meshri, D.T. Kirk-Othmer Encyclopedia of Chemical Technology; Fluorine Compounds, Inorganic, Iron, 5th ed.; John Wiley \& Sons, Inc.: Hoboken, NJ, USA, 2000. 